\title{
Biological and physical factors affecting the colonization of vegetation-free patches in a SW Atlantic salt marsh
}

\author{
Julieta Kaminsky ${ }^{1, *}$, Juan Alberti ${ }^{2}$, Martín Aguiar ${ }^{1}$, Oscar Iribarne ${ }^{2}$ \\ ${ }^{1}$ Facultad de Agronomía, Cátedra de Ecología, \\ Instituto de Investigaciones en Fisiología y Ecología Vinculadas a la Agricultura (IFEVA), Consejo Nacional de \\ Investigaciones Científicas y Técnicas (CONICET), Universidad de Buenos Aires, Buenos Aires, Argentina \\ ${ }^{2}$ Facultad de Ciencias Exactas y Naturales (FCEyN), Laboratorio de Ecología, \\ Instituto de Investigaciones Marinas y Costeras (IIMYC), Consejo Nacional de Investigaciones Científicas y Técnicas \\ (CONICET), Universidad Nacional de Mar del Plata (UNMDP), Mar del Plata, Argentina
}

\begin{abstract}
In many Northern Hemisphere salt marshes, recovery of disturbance-generated bare areas usually occurs within a few years. However, in some southwestern Atlantic marshes, bare patches may remain unchanged for several years. Here we investigated biological and physical factors that might affect bare patch colonization in a Mar Chiquita coastal lagoon salt marsh (Argentina). We evaluated natural seedling emergence of the pioneer pickleweed plant Sarcocornia perennis, considering distance to mature plants and the herbivory/bioturbation exerted by the crab Neohelice granulata (using exclosures). Almost no seedling emergence was observed in patches distant from mature plants, while higher emergence resulted in close patches. Crab exclusion did not affect seedling counts. Nevertheless, most of these seedlings did not survive high-temperature months. We analyzed if colonization was favored by increasing the availability of $S$. perennis seeds, and we found similar seedling emergence in patches both close and distant to mature plants. As in the previous experiment, most of them did not survive the high-temperature months, but some seedlings could establish within crab exclosures. Finally, we used a shade cloth to reduce solar radiation, but this did not increase seedling survival, which was only favored in crab exclosures. In summary, our results suggest that seed availability, followed by the presence of crabs (but not solar radiation), affect the rate of patch recovery. Additionally, our results show that life-history traits (seed ecology) of the colonizer can be a key and are a usually overlooked driver of salt marsh secondary succession.
\end{abstract}

KEY WORDS: Patch dynamics · Seedling emergence · Colonization · Sarcocornia perennis . Neohelice (Chasmagnathus) granulata · Seed dispersal · Bioturbation · Salt patches

\section{INTRODUCTION}

The colonization of vegetation-free zones is considered one of the key processes in the development of communities where natural or anthropogenic disturbance has initiated a secondary succession (e.g. Odum 1969, Grubb 1977, Pickett \& White 1985). A set of environmental filters that interact within differ- ent temporal scales will determine successional dynamics in each system (Morin 1999). In this respect, a variety of biotic and abiotic factors may affect pioneer species development and therefore delay or accelerate the covering of bare areas (Connell \& Slatyer 1977, Farrell 1991). The occurrence of natural disturbances which generate bare areas where a secondary succession starts is common in intertidal envi- 
ronments (e.g. Pennings \& Bertness 2001, Clarke 2004). Among the different factors involved in patch dynamics within intertidal communities, direct and indirect effects have been described for these systems, including positive (e.g. Bertness \& Leonard 1997) and competitive interactions (e.g. Levine et al. 1998), influence of consumers (e.g. Lubchenco \& Menge 1978), nutrient availability (e.g. Levine et al. 1998) and physical stress (e.g. Shumway \& Bertness 1992).

Understanding the relative importance of the factors that regulate successional dynamics is essential for conservation and management purposes. Particularly in salt marsh communities, the deposition of dead plants transported by tides (i.e. wrack) promotes the mortality of the vegetation (Brewer et al. 1998), changing relative abundances and generating bare patches when the disturbance persists in the long term (Bertness \& Ellison 1987). The colonization of these vegetation-free patches is strongly conditioned by the spatial variation in biotic and abiotic stressors characteristic of these systems, which generate spatial patterns that determine the structure of communities dominated by a small number of species (Chapman 1974, Shumway \& Bertness 1992, Bertness \& Hacker 1994). It has been observed that successional dynamics in post-disturbed areas in New England (USA) salt marshes involve a series of species that depend on these openings and that after colonizing those areas, they promote its closure in a period of about 3 yr (Bertness \& Ellison 1987). The establishment possibilities of different species strongly depends on their location within the intertidal, which in turn determines the relative importance of the factors involved: salinity and flooding frequency (Shumway \& Bertness 1992), propagule availability (Rand 2000), competition (Bertness \& Hacker 1994), presence of consumers and bioturbators (Pennings \& Bertness 2001). Commonly, after pioneer species colonize, they shade the surface and reduce the salinity stress, facilitating the invasion of less tolerant but competitively dominant species over relatively short periods of time (Bertness \& Leonard 1997).

The biotic factors that may have significant effects on germination and seedling establishment of pioneer species include certain characteristics of these species as well as interactions with other species and the abiotic environment (Friess et al. 2012). The establishment of marsh plants through seedlings can be strongly reduced by the presence of herbivores and/or ecosystem engineers (Crain 2008, Gedan et al. 2009, Alberti et al. 2010a). For example, poly- chaetes are known for their negative impact on seed availability and seedling survival of marsh pioneer species through herbivory and bioturbation (Paramor \& Hughes 2004). In addition, crabs can bury seeds through their burrowing activities and at the same time maintain and expand bare patches by grazing on seedlings and new shoots (Alberti et al. 2010a, Daleo et al. 2011). Regarding characteristics of the pioneer species, the number of available seeds may play an important role in the colonization of bare areas. Indeed, experimental seed additions in southern New England salt marshes resulted in an increase in plant cover (Rand 2000). Different factors may limit the availability of seeds, including herbivory, sediment entrapment or tidal export (Shumway \& Bertness 1992).

Among the abiotic factors that impose strong control on germination and seedling establishment of pioneer species, salinity plays a key role in delaying the time to germination or reducing the seedling fitness (Shumway \& Bertness 1992). Commonly, bare patches tend to become hypersaline because of increased porewater evaporation (caused by the lack of shading by the vegetation), which in turn limits their colonization by pioneer species (Bertness et al. 1992). Seeds of halophytic plants have the capacity to sustain their viability and recover after being exposed to high salinities, allowing germination when the stress is relaxed (Freitas \& Costa 2014). However, high variability exists between marsh plant species in their ability to germinate in high salt conditions (Khan et al. 2000). Moreover, as temperature and solar radiation increase in summer, desiccation and sediment salinity increase as well, contributing to the persistence of bare patches (Bertness 1991).

Succession models have been proposed for many salt marshes from the Northern Hemisphere, where the recovery of disturbance-generated bare areas occurs within 3 yr (Pennings \& Bertness 2001). In the Southern Hemisphere, however, previous observations revealed that bare patches found on the southwestern (SW) Atlantic Mar Chiquita coastal lagoon $\left(37^{\circ} 44^{\prime} \mathrm{S}, 57^{\circ} 26^{\prime} \mathrm{W}\right.$, Argentina) remain almost unchanged for more than 4 yr (Daleo et al. 2011). Thus, the aim of our study was to determine which biological and physical factors condition the colonization of bare patches in a SW Atlantic salt marsh. For this purpose, we evaluated the following hypotheses: (1) the number of seeds of the pioneer plant (Sarcocornia perennis) available on bare patches is not enough to overcome the environmental (i.e. abiotic and biotic) filters, (2) the herbivory and/or bioturbation pressure exerted by the intertidal crab Neohelice granulata 
plays a key role in germination and seedling survival of the pioneer plant and (3) the physical stress imposed by desiccation is an important control in seedling survival.

\section{MATERIALS AND METHODS}

\section{Study site}

This study was conducted at the Mar Chiquita coastal lagoon, a UNESCO Man and the Biosphere reserve. Salt marshes within this area can be classified as SW Atlantic temperate marshes, which extend from southern Brazil $\left(31^{\circ} \mathrm{S}\right)$ to northern Argentinean Patagonia $\left(43^{\circ} \mathrm{S} ;\right.$ Isacch et al. 2011). The strong freshwater input from the basin in Mar Chiquita leads to the dominance of Spartina densiflora, relegating Sarcocornia perennis to isolated areas (Isacch et al. 2006). The Mar Chiquita lagoon presents semidiurnal microtides with $0.79 \mathrm{~m}$ of tidal amplitude (Isacch et al. 2011). Lagoon salinity shows strong spatial variations, with a range of 0 to $35 \%$, depending on the considered area (Reta et al. 2001). Considering precipitation and temperature patterns, this area corresponds to a temperate subwet-wet system (Isla \& Gaido 2001, Canepuccia et al. 2013). During the study period, the average monthly temperature was similar to the historical range, while precipitation was $~ 40 \%$ lower during the first 3 mo after Sarcocornia perennis germination (August to October) followed by months with higher than average precipitation (data from the Servicio Meteorológico Nacional Argentino for the Mar del Plata airport station, $37^{\circ} 56^{\prime} \mathrm{S}, 57^{\circ} 35^{\prime} \mathrm{W}$, located $25 \mathrm{~km}$ south of our study site with similar geographic characteristics; Table S1 in the Supplement at www.int-res.com/articles/ suppl/m531p033_supp.pdf).

The halophytic perennial shrub Sarcocornia perennis is distributed over different salt marshes around the world, including the southern and western coasts of Europe, the southern coasts of Africa, and Brazil, Uruguay and Argentina in the western Atlantic (Davy et al. 2006). This species is commonly found in SW Atlantic marshes colonizing vegetation-free patches and promoting the establishment of the competitively dominant species Spartina densiflora through reduced crab herbivory rates $(S$. perennis structure impedes crab access to $S$. densiflora leaves) at low intertidal elevations (Alberti et al. 2008). Sarcocornia perennis is able to preserve viability and germinate under high salinity conditions, even though germination is reduced with increasing salinity (Davy et al. 2006).
The burrowing crab Neohelice (Chasmagnathus) granulata is a herbivore-detritivore macroinvertebrate that dominates SW Atlantic salt marshes (e.g. Bortolus \& Iribarne 1999). Its wide distribution along tidal flats and marshes, in addition to its role as a herbivore and ecosystem engineer, place this species among the most important biological factors in the structuring of SW Atlantic marshes (e.g. Iribarne et al. 1997, Alberti et al. 2015). Although N. granulata feeds mainly on Spartina spp. (e.g. Botto et al. 2005), it also negatively affects the distribution of Sarcocornia perennis through bioturbation and herbivory (Alberti et al. 2010a), and therefore it may determine the possibilities of colonization of vegetation-free patches.

\section{Effects of seed source distance and crabs on natural seedling emergence}

To evaluate whether the distance to mature $S$. perennis (i.e. those producing seeds) results in differences in seedling emergence, bare patches were randomly chosen at an intermediate intertidal elevation within the following 2 categories: bare patches close to and bare patches distant from mature $S$. perennis (i.e. 0.75 and $11 \mathrm{~m}$, respectively, with an average area of $6 \mathrm{~m}^{2}$; hereafter 'close' and 'distant' patches, respectively). In addition, to determine the joint effect of herbivory and bioturbation exerted by $N$. granulata on $S$. perennis seedlings, 3 treatments were defined in each of those 2 categories $(50 \times$ $50 \mathrm{~cm}, 8$ replicates) during February 2011: crab exclosures, cage controls and undisturbed controls. Crab exclusion plots were surrounded by a $40 \mathrm{~cm}$ high, $1 \mathrm{~cm}$ mesh size plastic fence. Cage controls were like exclosures but with 3 sides instead of 4 , allowing free movement of crabs. Seedlings within plots were counted on a monthly basis in each plot $(2$ bare patch categories $\times 3$ treatments $\times 8$ replicates $=$ 48 plots) from August (right after the first seedlings emerged) until November, when seedlings reached the vegetative stage (following Davy et al. 2006). These vegetative plants were counted again when flowering, in March 2012.

\section{Effects of seed availability on bare patch colonization}

To determine whether the number of seeds is a limiting factor in the colonization of bare patches, approximately $50 \mathrm{~S}$. perennis seeds were added in each 
of the plots described above within small baskets, to avoid confusion with the natural seedling emergence. Small baskets were made using a $1 \mathrm{~mm}^{2}$ plastic mesh $(2.5 \times 7 \mathrm{~cm} \times 4.5 \mathrm{~cm})$. They were filled with sediment from the bare patch, and then seeds were added on the surface. These seeds were collected from neighboring $S$. perennis plants during April 2011 , at the peak of seed availability. Given that many of the seeds that we collected were empty, a regression was estimated to add 50 filled seeds in each small basket using weight as a proxy of seed number. Seed samples of different weights were prepared, and then filled seeds were counted within each sample using a magnifying glass. Finally, a regression analysis was performed between sample weight and the number of filled seeds (linear regression model: $y=1308 x+6.7056 ; \mathrm{r}^{2}=0.76 ; F=33.82$, $\mathrm{df}=1,11, \mathrm{p}=0.0001$ ). Seeds were added just before the start of their natural emergence in July to avoid processes that might act before germination, like bioturbation (Alberti et al. 2010a). Seedlings within the small baskets were counted biweekly until they reached the vegetative stage (November 2011) and then again when flowering (March 2012).

\section{Sediment salinity and water content}

To evaluate if the seedling emergence and survival observed was associated with changes in sediment salinity or water content, sediment samples were taken bimonthly from each plot between March 2011 and January 2012 and processed in the lab following Alberti et al. (2010b).

\section{Effect of reduced sunlight on bare patch colonization}

To analyze whether the presence of post-germination environmental filters, particularly desiccation, might limit colonization, a third experiment was performed in a $400 \mathrm{~m}^{2}$ area with similar environmental conditions but with higher $S$. perennis abundance. In June 2011, and coinciding with natural seedling emergence, 40 plots $(25 \times 25 \times 30 \mathrm{~cm}$ high, 8 replicates) close to mature $S$. perennis plants were established. Eight of those plots were randomly assigned to each of the following treatments: (1) crab exclosures, (2) cage controls and (3) undisturbed controls without shade, in addition to (4) crab exclosures and (5) undisturbed controls with shade. Crab exclosures and cage controls were fenced as described above.
Shade treatments consisted of the addition of a shade cloth at the top and the highest half of each side (i.e. 15 to $30 \mathrm{~cm}$ high in each of the 4 sides of each replicate) in early September, coinciding with temperature increases, and right after the peak in seedling counts observed in the results of previous sections. Incident solar radiation was measured in 4 replicates from each treatment with a LI-COR LI-1000 radiometer at around noon in the early fall (April 2012). The shade cloth addition as well as the plastic mesh fence used in exclosures caused a reduction in incident radiation. The incident radiation measured in controls was (mean $\pm \mathrm{SD}$ ) $1390 \pm 12.49 \mu \mathrm{mol} \mathrm{s}^{-1} \mathrm{~m}^{-2}$. The addition of shade caused an $87 \%$ reduction, on average $227 \pm 262.4 \mu \mathrm{mol} \mathrm{s}^{-1} \mathrm{~m}^{-2}$; inside exclosures was $57 \%$ less, on average $596 \pm 203.53 \mu \mathrm{mol} \mathrm{s}^{-1} \mathrm{~m}^{-2}$; and inside exclosures with shade was $77 \%$ less, on average $317 \pm 114.04 \mu \mathrm{mol} \mathrm{s} \mathrm{s}^{-1} \mathrm{~m}^{-2}$. Seedlings were counted just before shade cloth addition and 1 mo later (October 2011). From then on (November 2011), seedlings reached the vegetative stage, and we measured them again at the end of the summer (March 2012). None of the surviving vegetative plants produced flowers.

\section{Statistical analysis}

All analyses were performed using $\mathrm{R}$ statistical software (3.1.2). ANOVAs were performed following the recommendations of Zar (2010); generalized linear models (GLMs) and zero-inflated negative binomial (ZINB) models were performed following the recommendations of Zuur et al. (2009). Below we present the analysis details for each experiment.

Effects of seed source distance and crabs on natural seedling emergence. To evaluate the separate and interactive effect of crab exclusion treatments and bare patch location (close to and distant from mature $S$. perennis) on the number of seedlings, we did a Poisson GLM (for the first 2 sampling dates), detected overdispersion and corrected the standard errors using a quasi-GLM model, where the variance is given by $\varphi \times \mu$, where $\mu$ is the mean, and $\varphi$ is the dispersion parameter (see Zuur et al. 2009). Given that for the last sampling date for seedlings as well as vegetative and flowering plants we found an excessive number of zeros, we did a ZINB (see Zuur et al. 2009).

Effects of seed availability on bare patch colonization. To evaluate the separate and interactive effect of crab treatments and bare patch location on the number of seedlings, we did a Poisson GLM as described above. Given that for vegetative and flow- 
ering plants we found an excessive number of zeros, we did a ZINB.

Sediment salinity and water content. Sediment salinity (March and August 2011 log-transformed) and water content (August 2011 square root-transformed, January 2012 reciprocal square root-transformed) were compared between bare patch condition and crab treatment using a 2-way ANOVA for each sampling date.

Effect of reduced sunlight on bare patch colonization. To evaluate the separate and interactive effect of crab treatments and shade on the number of seedlings, we did a Poisson GLM as described above. Given that for vegetative and flowering plants we found an excessive number of zeros, we did a ZINB. For each dependent variable and sampling date, controls were compared against cage controls and no cage effects were found.

\section{RESULTS}

\section{Effects of seed source distance and crabs on natural seedling emergence}

Almost no natural emergence of Sarcocornia perennis was found in distant patches. In contrast, many more seedlings, that gradually decreased in number over time, were found in close patches: 21 times more in August, 18 times more in September and 5 times more in October (Fig. 1; August, Poisson GLM: $F=$ 59.94, df =1, 46, $\mathrm{p}<0.001$; September, Poisson GLM: $F=48.74, \mathrm{df}=1,46, \mathrm{p}<0.001$; October, final ZINB model $=$ seedlings $\sim$ distance $\mid 1: \chi^{2}=10.75, \mathrm{df}=1, \mathrm{p}=$ $0.001)$. However, crab exclusion treatments did not affect the number of seedlings at any given sampling date, and this variable was never retained in the final model. Even though some seedlings were able to survive and reach the vegetative and flowering stages only within crab exclosures, neither distance to mature $S$. perennis nor exclusion treatments played a significant role in vegetative or flowering plant counts.

\section{Effects of seed availability on bare patch colonization}

The observed differences in naturally emerged seedlings between close and distant patches disappeared after seed addition (distance to mature $S$. perennis was never retained in the final model, except for late September, when there were more

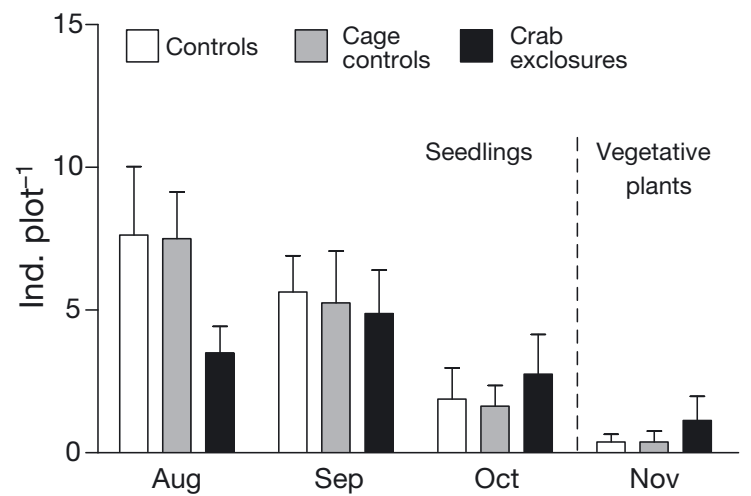

Fig. 1. Seedling emergence (mean + SE) of Sarcocornia perennis in the different treatments deployed on bare patches close to mature $S$. perennis (seed sources). November (spring) measurements correspond to vegetative plants. Natural seedling emergence from distant patches is not presented because almost no emergence was found

seedlings close to than distant from mature $S$. perennis; Poisson GLM, distance $\times$ treatment interaction: $F=5.63, \mathrm{df}=2,42, \mathrm{p}=0.007)$ but followed the same temporal pattern (Fig. 2). Exclusion of crabs did not affect seedling or flowering plant counts, but more vegetative plants were found inside the exclosures than in the control plots (final ZINB model $=$ vegetative $\sim$ treatment I 1: $\chi^{2}=8.06, \mathrm{df}=2, \mathrm{p}=0.018$ ).

\section{Sediment salinity and water content}

There were no differences in sediment salinity or in water content, either between close and distant patches or between crab exclusion treatments (except for higher salinities in control plots during March 2011), but as in the previous section, a temporal pattern was found (Tables S2-S4 in the Supplement at www.int-res-com/articles/suppl/m531p033. supp.pdf). During winter, salinity showed minimum values, while during spring and summer months it was more than 3 times higher. Sediment water content followed the opposite pattern: values were highest during autumn and winter but were $50 \%$ reduced during higher temperature months.

\section{Effect of reduced sunlight on bare patch colonization}

After addition of shade cloth, there were more seedlings and vegetative plants in crab exclosures than on control plots (Fig. 3; October, Poisson GLM: $F=6.12, \mathrm{df}=1,30, \mathrm{p}=0.019$; November, final ZINB model $=$ vegetative $\sim$ treatment I $1: \chi^{2}=10.28, \mathrm{df}=1$, 


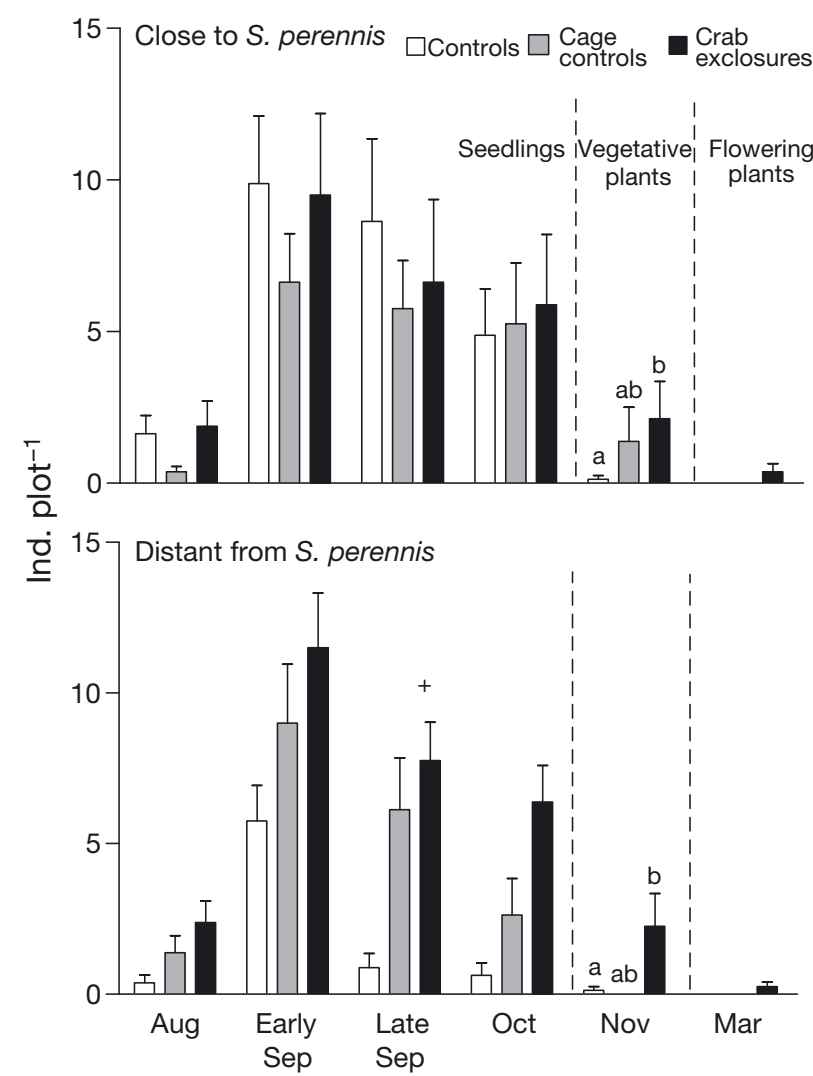

Fig. 2. Seedling emergence (mean $+\mathrm{SD}$ ) of Sarcocornia perennis after seed addition in the different treatments deployed on bare patches close to and distant from mature $S$. perennis (seed sources). November (spring) measurements correspond to vegetative plants, and March (late summer) measurements correspond to flowering plants. Significant differences between close and distant patches in late September are indicated with ' + ', while letters denote significant differences between treatments

$\mathrm{p}=0.001 ;$ March, final ZINB model $=$ vegetative $\sim$ treatment | $1: \chi^{2}=10.39, \mathrm{df}=1, \mathrm{p}=0.001$ ). Shading did not show a significant effect on the number of individuals on any of the sampling dates, though exclosures with shading exhibited $25 \%$ more vegetative plants in total than exclosures without shading (i.e. 15 vs. 12) as well as more replicates with vegetative plants (6 vs. 4) during our last sampling date.

\section{DISCUSSION}

Our results show that in Mar Chiquita salt marshes, successful colonization of vegetation-free patches by Sarcocornia perennis is determined by the combination of biotic and abiotic forces that act on stages prior to and after seed germination. The availability of $S$. perennis seems to be the most important filter given that differences in natural emergence between

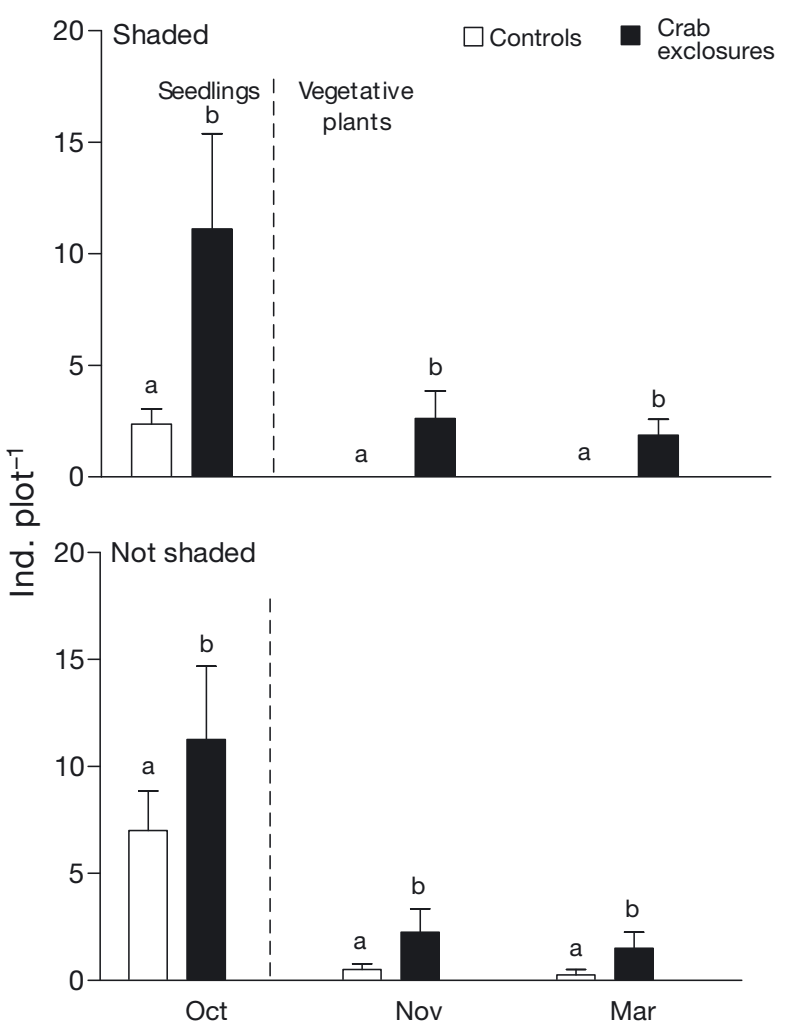

Fig. 3. Seedling emergence (mean $+\mathrm{SD}$ ) of Sarcocornia perennis in undisturbed controls and crab exclosures from shaded and unshaded plots. November (spring) and March (late summer) measurements correspond to vegetative plants. Letters denote significant differences between crab treatments for a given date

close and distant patches disappeared with the addition of seeds. The exclusion of crabs did not have a consistent effect over time, with no effect on seedling survival but a positive effect on vegetative plants. However, among the 660 seedlings we counted during the whole experiment, only 11 became vegetative and flowering plants, and all of them were found growing within exclosures. In addition, we also observed a strong decrease in survival coincident with increases in sediment salinity and decreases in water content, but the addition of shade did not affect seedling survival. Most importantly, our results reveal that seed ecology (i.e. production, dispersal, survival and establishment) of the pioneer species can be a key and this is a usually overlooked driver of salt marsh patch dynamics.

\section{Seed availability}

There are some studies showing that seed availability plays a key role in the recovery and species 
assemblages of salt marshes. For example, seed availability was considered the most important factor determining the sequence of species establishment during a salt marsh restoration in Belgium (Erfanzadeh et al. 2010). Seed availability on a particular salt marsh area is strongly dependent on seed dispersal, which could occur by abiotic and biotic drivers. Among these drivers, tidal waters seem to play a prominent role (Bakker et al. 1985). However, dispersal is not necessarily always high. Rand (2000) showed that seed availability in New England (USA) salt marshes was likely the result of localized dispersal (i.e. seed distributions resembled adult plant distributions). However, subsequent seedling survival was also limited by post-dispersal factors such as competition and abiotic stress.

Our results mostly coincide with this evidence, particularly with those of Rand (2000). The distance to seed sources appears to strongly condition the arrival of seeds to the vegetation-free patches. As was proposed in our first hypothesis, the dispersal of $S$. perennis seeds from adult individuals could be a strong environmental filter that limits colonization in these marshes and thereby delays secondary succession. In this context, the existence of a Spartina densiflora matrix might be acting as a natural barrier for seed dispersal, given that bare patches and Sarcocornia perennis plants occur sparsely within this matrix (Daleo et al. 2011).

\section{Plant-animal interactions}

The dynamics of salt marsh successions are also known to be influenced by plant-animal interactions. For example, bioturbation and herbivory by polychaetes or crabs can reduce the availability of seeds and seedlings of pioneer salt marsh plants (Paramor \& Hughes 2004, Alberti et al. 2010a). In addition, seed consumption by hares and geese does not have a strong impact on seed dispersal, and seed viability is reduced after digestion (Chang et al. 2005). Furthermore, the consumption of seedlings of the dominant plant species by rodents has been shown to slow down bare patch recovery (Gedan et al. 2009, Daleo et al. 2014). Herbivory on established plants can also slow down primary and secondary succession (Kuijper et al. 2004, Alberti et al. 2008).

Based on this information and according to previous studies in Mar Chiquita salt marshes (Alberti et al. 2010a), we were expecting to observe more emergence and seedling survival within crab exclusions. However, we found that crabs only reduced the abundance of vegetative plants, while they did not reduce the number of seedlings and flowering plants. This might have occurred because crabs are more active at lower elevations (Alberti et al. 2007), but wrack-generated bare patches are usually found at higher elevations (Brewer et al. 1998). In addition, the extremely low numbers of plants that reached the flowering stage (only 11 plants produced flowers, and all of them were growing within exclosures) might also reduce the chances of detecting differences between treatments. Whatever the case, it is clear that compared to seed availability, herbivory and bioturbation played a comparatively minor role in patch dynamics, and therefore our second hypothesis was not supported.

\section{Abiotic stress}

Desiccation and the associated increases in salinity have been described as other strong forces regulating bare patch dynamics in salt marshes. For example, Shumway \& Bertness (1992) explored the role of seed addition and sediment salinity on the bare patch dynamics of New England (USA) salt marshes and found that emergence and survival was favored when the salinity was decreased. Indeed, positive interactions are essential for the full recovery of these bare patches, with the pioneer species ameliorating the otherwise too high salinities (due to the increased solar radiation that takes place after the loss of the vegetation cover) for the late successional species (Bertness \& Leonard 1997, Pennings \& Bertness 2001). However, pioneer species might also suffer from abiotic forces during their establishment, such as current velocities (Bouma et al. 2009a), and their establishment might not be possible below a threshold shoot density (enough to reduce current velocity; Bouma et al. 2009b). In these scenarios, a momentary relaxation of the stressful abiotic conditions (window of opportunity sensu Balke et al. 2014) will be necessary to allow the successful establishment of these pioneer species.

Even though we found a high mortality of seedlings that occurred simultaneously with higher sediment salinities and lower sediment water content, we did not find a significant effect of shading on seedling survival. These results suggest that solar radiation does not play a very important role in our study system. Alternatively, this lack of effect might have been an artifact. Lack of enough shading to prevent desiccation, too late or short shading addition or too few surviving vegetative plants could all 
explain why we found results that were contrary to our expectations. Regarding our third hypothesis, we propose that regardless of whether the effect of shading could have been significant or not, the role played by solar radiation is subordinate to the role played by seed availability and probably to crab presence as well.

\section{Secondary succession in SW Atlantic salt marshes}

The secondary succession and patch dynamics in SW Atlantic salt marshes has been previously studied with a focus placed on the interactions between plant species that dominate these marshes, Spartina densiflora and Sarcocornia perennis (Alberti et al. 2008), and between these species and the crab Neohelice granulata (Alberti et al. 2010a, Daleo et al. 2011). These studies showed that after colonizing, Sarcocornia perennis facilitates the establishment of Spartina densiflora through reduced herbivory rates and is finally displaced by the higher competitive ability of $S$. densiflora. Overall, N. granulata retards succession dynamics through bioturbation prior to the germination of Sarcocornia perennis and through herbivory and bioturbation on $S$. perennis seedlings (Alberti et al. 2010a). Herbivory also retards later stages of succession, negatively affecting Spartina densiflora once this species colonizes Sarcocornia perennis patches (Alberti et al. 2008). Finally, crab herbivory also prevents the asexual closure of disturbance-generated bare areas (Daleo et al. 2011).

However, our results reveal that the secondary successions in these marshes are not entirely driven by biological interactions (i.e. facilitation, competition, herbivory or bioturbation). Our experimental approach allows us to include seed availability to the factors that would be promoting the persistence of vegetation-free patches in these salt marshes. Moreover, our results suggest windows of opportunity (see Balke et al. 2014), in which seed availability is increased and probably crab activities and salinity are decreased to reach the threshold of Sarcocornia perennis abundance needed to guarantee bare patch closure. Future studies could focus on dispersal dynamics inside the matrix (following Nathan \& Muller-Landau 2000), and how salinity and crabs influence seed viability, to evaluate potential thresholds in this apparent bottleneck of seed availability. Finally, our results show that life-history traits (seed ecology) of the colonizer can be a key and are a usually overlooked driver of salt marsh secondary succession.
Acknowledgements. We thank the Servicio Meteorológico Nacional Argentino for providing the rainfall and temperature data base. This project was supported by grants from the Universidad Nacional de Mar del Plata, CONICET and the Agencia Nacional de Promoción Científica y Tecnológica.

\section{LITERATURE CITED}

Alberti J, Montemayor D, Álvarez F, Méndez Casariego A and others (2007) Changes in rainfall pattern affect crab herbivory rates in a SW Atlantic salt marsh. J Exp Mar Biol Ecol 353:126-133

Alberti J, Escapa M, Iribarne OO, Silliman B, Bertness M (2008) Crab herbivory regulates plant facilitative and competitive processes in Argentinean marshes. Ecology 89:155-164

Alberti J, Escapa M, Daleo P, Méndez Casariego A, Iribarne OO (2010a) Crab bioturbation and herbivory reduce preand post-germination success of Sarcocornia perennis in bare patches of SW Atlantic salt marshes. Mar Ecol Prog Ser 400:55-61

Alberti J, Méndez Casariego A, Daleo P, Fanjul E, Silliman B, Bertness M, Iribarne OO (2010b) Abiotic stress mediates top-down and bottom-up control in a southwestern Atlantic salt marsh. Oecologia 163:181-191

Alberti J, Daleo P, Fanjul E, Escapa M, Botto F, Iribarne O (2015) Can a single species challenge paradigms of salt marsh functioning? Estuaries Coasts 38:1178-1188

Bakker JP, Dijkstra M, Russchen PT (1985) Dispersal, germination and early establishment of halophytes and glycophytes on a grazed and abandoned salt-marsh gradient. New Phytol 101:291-308

Balke T, Herman PMJ, Bouma TJ (2014) Critical transitions in disturbance-driven ecosystems: identifying windows of opportunity for recovery. J Ecol 102:700-708

> Bertness MD (1991) Interspecific interactions among high marsh perennials in a New England salt marsh. Ecology 72:125-137

> Bertness MD, Ellison AM (1987) Determinants of pattern in a New England salt marsh plant community. Ecol Monogr 57:129-147

> Bertness MD, Hacker SD (1994) Physical stress and positive associations among marsh plants. Am Nat 144:363-372

> Bertness MD, Leonard GH (1997) The role of positive interactions in communities: lessons from intertidal habitats. Ecology 78:1976-1989

> Bertness MD, Gough L, Shumway SW (1992) Salt tolerances and the distribution of fugitive salt marsh plants. Ecology 73:1842-1851

Bortolus A, Iribarne O (1999) Effects of the SW Atlantic burrowing crab Chasmagnathus granulata on a Spartina saltmarsh. Mar Ecol Prog Ser 178:79-88

Botto F, Valiela I, Iribarne O, Martinetto P, Alberti J (2005) Impact of burrowing crabs on $\mathrm{C}$ and $\mathrm{N}$ sources, control, and transformations in sediments and food webs of SW Atlantic estuaries. Mar Ecol Prog Ser 293:155-164

Bouma TJ, Friedrichs M, Klaassen P, van Wesenbeeck BK and others (2009a) Effects of shoot stiffness, shoot size and current velocity on scouring sediment from around seedlings and propagules. Mar Ecol Prog Ser 388: 293-297

> Bouma TJ, Friedrichs M, van Wesenbeeck BK, Temmerman S, Graf G, Herman PMJ (2009b) Density-dependent linkage of scale-dependent feedbacks: a flume study on 
the intertidal macrophyte Spartina anglica. Oikos 118: 260-268

- Brewer JS, Levine JM, Bertness MD (1998) Interactive effects of elevation and burial with wrack on plant community structure in some Rhode Island salt marshes. J Ecol 86:125-136

Canepuccia AD, Pérez CF, Farina JL, Alemany D, Iribarne OO (2013) Dissimilarity in plant species diversity between salt marsh and neighboring environments decreases as environmental harshness increases. Mar Ecol Prog Ser 494:135-148

> Chang ER, Zozaya EL, Kuijper DPJ, Bakker JP (2005) Seed dispersal by small herbivores and tidal water: Are they important filters in the assembly of salt-marsh communities? Funct Ecol 19:665-673

Chapman VJ (1974) Salt marshes and salt deserts of the world. Interscience, New York, NY

> Clarke PJ (2004) Effects of experimental canopy gaps on mangrove recruitment: Lack of habitat partitioning may explain stand dominance. J Ecol 92:203-213

Connell JH, Slatyer RO (1977) Mechanisms of succession in natural communities and their role in community stability and organization. Am Nat 111:1119-1144

Crain CM (2008) Interactions between marsh plant species vary in direction and strength depending on environmental and consumer context. J Ecol 96:166-173

> Daleo P, Alberti J, Iribarne OO (2011) Crab herbivory regulates re-colonization of disturbed patches in a southern Atlantic salt marsh. Oikos 120:842-847

> Daleo P, Alberti J, Pascual J, Canepuccia A, Iribarne O (2014) Herbivory affects salt marsh succession dynamics by suppressing the recovery of dominant species. Oecologia 175:335-343

Davy AJ, Bishop GF, Mossman H, Redondo-Gómez S and others (2006) Biological flora of the British Isles: Sarcocornia perennis (Miller) AJ Scott. J Ecol 94:1035-1048

Erfanzadeh R, Garbutt A, Pétillon J, Maelfait JP, Hoffmann $M$ (2010) Factors affecting the success of early salt-marsh colonizers: seed availability rather than site suitability and dispersal traits. Plant Ecol 206:335-347

Farrell TM (1991) Models and mechanisms of succession: an example from a rocky intertidal community. Ecol Monogr 61:95-113

Freitas RF, Costa CSB (2014) Germination responses to salt stress of two intertidal populations of the perennial glasswort Sarcocornia ambigua. Aquat Bot 117:12-17

Friess DA, Krauss KW, Horstman EM, Balke T, Bouma TJ, Galli D, Webb EL (2012) Are all intertidal wetlands naturally created equal? Bottlenecks, thresholds and knowledge gaps to mangrove and saltmarsh ecosystems. Biol Rev Camb Philos Soc 87:346-366

Gedan KB, Crain CM, Bertness MD (2009) Small-mammal herbivore control of secondary succession in New England tidal marshes. Ecology 90:430-440

Grubb PJ (1977) The maintenance of species-richness in plant communities: the importance of the regeneration niche. Biol Rev Camb Philos Soc 52:107-145

Iribarne O, Bortolus A, Botto F (1997) Between-habitat differences in burrow characteristics and trophic modes in the southwestern Atlantic burrowing crab Chasmagnathus granulata. Mar Ecol Prog Ser 155:137-145
Isacch JP, Costa CSB, Rodríguez-Gallego L, Conde D, Escapa M, Gagliardini DA, Iribarne O (2006) Distribution of saltmarsh plant communities associated with environmental factors along a latitudinal gradient on the southwest Atlantic coast. J Biogeogr 33:888-900

Isacch JP, Escapa M, Fanjul E, Iribarne OO (2011) Valoración ecológica de bienes y servicios ecosistémicos en marismas del Atlántico sudoccidental. In: Laterra P, Jobbágy E, Paruelo J (eds) Valoración de servicios ecosistémicos. Conceptos, herramientas y aplicaciones para el ordenamiento territorial. Ediciones INTA, Buenos Aires, p 529-551

Isla FI, Gaido ES (2001) Evolución geológica de la laguna Mar Chiquita. In: Iribarne O (2001) Reserva de biósfera Mar Chiquita: características físicas, biológicas y ecológicas. Editorial Martín, Mar del Plata, p 19-30

> Khan MA, Gul B, Weber DJ (2000) Germination responses of Salicornia rubra to temperature and salinity. J Arid Environ 45:207-214

> Kuijper DPJ, Nijhoff DJ, Bakker JP (2004) Herbivory and competition slow down invasion of a tall grass along a productivity gradient. Oecologia 141:452-459

- Levine JM, Hacker SD, Harley CDG, Bertness MD (1998) Nitrogen effects on an interaction chain in a salt marsh community. Oecologia 117:266-272

Lubchenco J, Menge BA (1978) Community development and persistence in a low rocky intertidal zone. Ecol Monogr 48:67-94

Morin PJ (1999) Community ecology. Blackwell, Oxford

Nathan R, Muller-Landau HC (2000) Spatial patterns of seed dispersal, their determinants and consequences for recruitment. Trends Ecol Evol 15:278-285

> Odum EP (1969) The strategy of ecosystem development. Science 164:262-270

Paramor OAL, Hughes RG (2004) The effects of bioturbation and herbivory by the polychaete Nereis diversicolor on loss of saltmarsh in south-east England. J Ecol 41: 449-463

Pennings SC, Bertness MD (2001) Salt marsh communities. In: Bertness MD, Gaines SD, Hay M (eds) Marine community ecology, Vol 11. Sinauer Associates, Sunderland, MA, p 289-316

Pickett STA, White PS (eds) (1985) The ecology of natural disturbance and patch dynamics. Academic Press, San Diego, CA

> Rand TA (2000) Seed dispersal, habitat suitability and the distribution of halophytes across a salt marsh tidal gradient. J Ecol 88:608-621

Reta R, Martos PP, Perillo GME, Piccolo MC, Ferrante A (2001) Características hidrográficas del estuario de la laguna Mar Chiquita. In: Iribarne O (ed) Reserva de biosfera Mar Chiquita: características físicas, biológicas y ecológicas. Editorial Martín, Mar del Plata, p 31-52

Shumway SW, Bertness MD (1992) Salt stress limitation of seedling recruitment in a salt marsh plant community. Oecologia 92:490-497

Zar JH (2010) Biostatistical analysis. Prentice-Hall, Upper Saddle River, NJ

Zuur A, Ieno EN, Walker N, Saveliev AA, Smith GM (2009) Mixed effects models and extensions in ecology with R. Springer Science \& Business Media, New York, NY

Submitted: October 27, 2014; Accepted: April 26, 2015 Proofs received from author(s): June 19, 2015 